\section{Peripheral Neuritis After Addiction to Petrol}

Brit. med.F., 1966, 1, 216

Reports of accidental petrol poisoning are well known (Cassells and Dodds, 1946 ; Aidin, 1958 ; Ainsworth, 1960 ; Saxton, 1960). Self-induced petrol poisoning is rare (Pruitt, 1959 ; Oldham, 1961 ; Bethell, 1965). This case is of interest as it appears to be the first instance of intoxication due to petrol consumption resulting from the triorthocresyl phosphate content of petrol.

\section{Case Report}

A 20-year-old motor mechanic accidentally drank petrol while siphoning a tank when he was 17 years old. Thereafter he took about a litre of petrol a week, either drinking it or more frequently inhaling a soaked wad, oblivious of everything else.

Five months before admission he developed weakness of the left leg and a month later of the right one. The weakness steadily increased over the next three months. He found that his feet were floppy and he could not move his toes easily. He also had difficulty in getting up from the squatting position.

For three months there had been a progressive weakness of both upper limbs, the distal part being more affected. He could not straighten the fingers completely, and had occasional tingling and numbness in both hands.

Examination revealed an intelligent, co-operative patient, keen on overcoming the addiction. The positive findings were that there was Grade 4 power in the flexors and extensors of the elbows, with generalized flaccidity, more marked at the wrists. There was early bilateral claw deformity. He had a bilateral foot-drop and could not move the toes at all. The dorsiflexors and evertors of the ankle showed Grade 2 power. Cutaneous sensations were very slightly impaired below the wrists and ankles. The reflexes in the upper limbs were sluggish and were absent in the lower limbs; the abdominal reflexes were preserved and the plantars flexor.

Haematological examination was normal, except for an E.S.R. of $47 \mathrm{~mm}$./hour (Westergren). The C.S.F. was normal. A biopsy was performed on the right tibialis anterior muscle and the sural nerve. This revealed the type of picture associated with chronic dermatomyositis-a normal sural nerve, severe fibrinoid degeneration of the collagen and vasculitis in the dermal connective tissue, with predominant muscle atrophy and occasional muscle necrosis and/or regeneration.

For the first week in hospital the patient found it difficult to overcome the addiction. However, he settled down and gradually improved. He was discharged after five weeks, having received physiotherapy, a course of corticosteroids, vitamin $\mathbf{B}_{1}$ and $\mathbf{B}$ complex. Eight months later he had recovered completely and was a studio-camera operator. Two years later there had been no relapse.

\section{COMMENT}

Petrol or gasoline is a petroleum distillate consisting of saturated and unsaturated hydrocarbons with a high proportion of the aromatic variety. Tricresyl phosphate is added to make for smoother running by controlling pre-ignition. The maximum content incorporated in the motor petrol sold in India is $0.013 \%$ by weight, generally varying between $0.0016 \%$ and $0.0044 \%$ by weight (Coates, 1961). Cresyl phosphates occur as a mixture of ortho, meta, and para esters. Orthocresyl phosphate is highly toxic to the nervous system, while the meta and para cresyl esters, as well as the phenyl esters, do not share this property of a specific attack on the motor nerves. Toxicity due to triorthocresyl phosphate has been reported extensively (Burley, 1932 ; Aring, 1942 ; Hotston, 1946 ; Smith and Spalding, 1959 ; Travers, 1962 ; Vora et al., 1962).
In poisoning due to triorthocresyl phosphate the symptoms start with a rapidly developing peripheral neuritis, essentially of the motor variety, giving rise to a bilateral flaccid foot-drop with absent ankle jerks, and, later, a wrist drop. Cramp and paraesthesiae have been known to precede this. The prognosis is usually good if the offending agent is eschewed severely, but recovery may be slow (Vora et al., 1962). The histological changes in the skin and central nervous system in triorthocresyl phosphate poisoning have been described previously (Aring, 1942 ; Cavanagh, 1954 ; Vora et al., 1962). Essentially the picture is that of a chronic polymyositis or dermatomyositis.

The clinical and histological picture in this case is similar to that seen in poisoning due to triorthocresyl phosphate, though this organic compound has not been incriminated before in chronic petrol poisoning. The patient had weakness of both lower limbs with a bilateral foot-drop. There was paraesthesia in the upper limbs followed by an early claw deformity. Sensory changes were minimal. The upper limb reflexes were sluggish, and those in the lower limbs were absent. The biopsy showed neurogenic muscular atrophy with evidence of collagen degeneration in the skin and occasional muscle necrosis and regeneration, which are similar to the pathological changes described with proved intoxication due to triorthocresyl phosphate, as noted above (Vora et al., 1962). After refraining completely from drinking or inhaling petrol the patient made a gradual but total recovery.

Tetraethyl lead is another constituent of petrol, which is added in a small amount as an anti-knock substance. The maximum quantity of tetraethyl lead added to Indian petrol is about $0.09 \%$ by weight, varying between $0.01 \%$ and $0.03 \%$ by weight (Coates, 1961). However, tetraethyl lead poisoning does not give rise to a peripheral neuropathy but to a gastro-intestinal upset, irritability, a confusional state, and convulsions. Hence, tetraethyl lead cannot be incriminated as the source of intoxication in the patient reported on here, for he showed none of these symptoms.

The clinical and pathological features detailed above in this case, when examined in the light of the known manifestations of triorthocresyl phosphate and tetraethyl lead poisoning, appear to have resulted from the former component of petrol.

I am very grateful to Dr. N. H. Wadia, under whose care the patient was admitted, for his constant help and advice. Thanks are also due to Dr. D. K. Dastur, of the Neuropathology Unit of the Indian Council of Medical Research, for the histopathology report and for his comments. I should like to thank the Dean of the J.J. Group of Hospitals for permission to publish this paper.

VINODH KARANI, M.D.,

Formerly Registrar, Department of Neurology, J. J. Group of Hospitals, Bombay.

\section{REFERENCES}

Aidin, R. (1958). Brit. med. F., 2, 369.

Ainsworth, R. W. (1960). Ibid., 1, 1547.

Aring, C. D. (1942). Bräin, 65, 34.

Bethell, M. F. (1965). Brit. med. f., 2, 276

Burley, B. T. (1932). 7. Amer. med. Ass.; 98, 298.

Cassells, D. A. K., and Dodds, E. C. (1946). Brit. med. f., 2, 681

Cavanagh, J. B. (1954). \}. Neurol. Neurosurg. Psychiat., 17, 163.

Coates, P. C. R. (1961). Personal communication.

Faucett, R. L., and Jensen, R. A. (1952). F. Pediat., 41, 364

Hotston, R. D. (1946). Lancet, 1, 207.

Hunter, D. (1955). The Diseases of Occupations. English Universities Press, London

Oldham, W. (1961). Brit. med. f., 2, 1687

Pruitt, M. (1959). F. Amer. med. Ass., 171, 2355.

Saxton, A. K. (1960). Brit. med. f., 2, 67.

Smith, H. V. and Spalding, J. M. K. (1959). Lancet, 2, 1019.

Travers, P. R. (1962). Proc. roy. Soc. Med., 55, 57.

Vora, D. D., Dastur, D. K., Braganca, B. M., Parihar, L. M., Iyer, C. G. S., Fondekar, R. B., and Prabhakaran, K. (1962). ₹. Neurol Neurosurg. Psychiat., 25, 234. 